\title{
Naar een systeem van docentbeoordeling
}

\author{
H.A.P. Wolfhagen, D.H.J.M. Dolmans, L.F.J.Th.M. Kolle, A.J.J.A. Scherpbier
}

\section{Samenvatting}

Onderwijsprestaties worden in toenemende mate betrokken bij de carrièremogelijkheden van medewerkers. Dit vereist dat onderwijsprestaties beoordeeld worden. Dit artikel beschrijft de stappen om te komen tot een plan van aanpak voor een systeem van docentbeoordeling. (Wolfhagen HAP, Dolmans DHJM, Kolle LFJThM, Scherpbier AJJA. Naar een systeem van docentbeoordeling. Tijdschrift voor Medisch Onderwijs 2000;19(6): 213-217.)

\section{Inleiding}

Binnen de opleiding geneeskunde vervult het merendeel van de docenten taken op het gebied van onderzoek, onderwijs en/of patiëntenzorg. Onderzoeksprestaties spelen de belangrijkste rol bij carrièremogelijkheden. Onderwijsprestaties zijn hierbij veelal van ondergeschikt belang. ${ }^{1}$ De vraag is in hoeverre dit terecht en wenselijk is. Om het belang van onderwijs te onderstrepen, dienen prestaties op dit terrein eveneens een rol te spelen bij carrièremogelijkheden. Enerzijds door onderwijsprestaties te betrekken bij de loopbaan van medewerkers en anderzijds door profilering op het gebied van onderwijs mogelijk te maken. De Visitatiecommissie Geneeskunde onderschrijft deze gedachte en pleit ervoor dat faculteiten duidelijk maken dat onderwijsinspanningen en -prestaties een carrièreperspectief openen dat minstens evenwaardig is met de carrièrelijn waar onderzoeksprestaties de prioriteit hebben. ${ }^{2}$

Indicatoren om de kwaliteit van onderwijsprestaties te beoordelen zijn hiervoor noodzakelijk. Het is algemeen geaccepteerd dat onderzoeksprestaties beoordeeld worden aan de hand van output in de vorm van publicaties, internationale contacten en het vermogen om fondsen te verwerven voor onderzoeksprojecten.
Onderwijsprestaties worden slechts sporadisch beoordeeld. Veelal wordt volstaan met het verstrekken van gegevens over de kwantiteit van de onderwijsactiviteiten (onderwijslast) zonder dat daarbij uitspraken gedaan worden over de kwaliteit.

Indien onderwijs een serieuze rol speelt in de loopbaan van medewerkers, dan moet duidelijk zijn welke bekwaamheden nodig zijn voor bepaalde onderwijsrollen en op welke manier deze beoordeeld worden. In dit artikel wordt een stappenplan beschreven om te komen tot een systeem van docentbeoordeling.

\section{Stappenplan voor een systeem van docentbeoordeling}

In binnen- en buitenland zijn diverse pogingen ondernomen om te komen tot een systeem van docentbeoordeling. ${ }^{3-5} \mathrm{Ge}$ meenschappelijke elementen hierin zijn onder meer het formuleren van de doelstelling, de wijze waarop docentbeoordelingen gebruikt worden, omschrijving van competenties, definiëring van de regels voor promotiebeleid en de keuze van beoordelingsinstrumenten. De Faculteit der Geneeskunde in Maastricht heeft een stappenplan gemaakt om te komen tot een systeem waarin de genoemde elementen zijn opgenomen. 
Stap 1. Formuleer wat het doel is van een systeem van docentbeoordeling

Het gebruiksdoel van docentbeoordelingen bepaalt het soort meetinstrumenten. Formulering van het doel van docentbeoordelingen moet daarom vooraf plaatsvinden. 6

Grofweg kunnen twee doelen onderscheiden worden. Het eerste doel is formatief: de beoordelingen zijn erop gericht docenten van individuele feedback te voorzien teneinde hun prestaties te verbeteren. Het tweede doel is selectief: de beoordelingen zijn erop gericht docenten te selecteren. In negatieve zin betekent dit dat docenten naar aanleiding van de beoordeling uitgesloten kunnen worden van bepaalde onderwijsrollen. In positieve zin betekent dit dat docenten de gelegenheid krijgen zich te profileren op het gebied van onderwijs.

\section{Stap 2. Inventariseer en benoem alle onder- wijsrollen}

Allereerst is het nodig om inzicht te verkrijgen in het totaal aan onderwijsrollen die binnen een instelling vervuld worden. Dit maakt een inventarisatie van onderwijsrollen noodzakelijk. Voorbeelden van onderwijsrollen zijn: uitvoerder van onderwijs (bijvoorbeeld tutor), beoordelaar, vakdeskundige, ontwikkelaar van leermaterialen, coördinator van een module. Het is mogelijk, maar niet noodzakelijk, om deze rollen in een en dezelfde persoon te verenigen.

\section{Stap 3. Maak voor elke onderwijsrol een taakomschrijving}

Aan elke onderwijsrol liggen bekwaamheden ten grondslag. ${ }^{7}$ Het benoemen van deze bekwaamheden per onderwijsrol maakt duidelijk wat de inhoud is van de diverse onderwijsrollen en welke activiteiten van docenten verwacht worden. Een goede taakomschrijving bevat een beschrijving van deze bekwaamheden. Hieruit is af te leiden aan welke eisen een docent moet voldoen om in aanmerking te komen voor deze rol. Deze taakomschrijving vormt de basis voor de formulering van criteria om de onderwijsprestaties van docenten te beoordelen.

Een beschrijving van een onderwijsrol wint aan praktische bruikbaarheid als hierin naast de gevraagde bekwaamheden ook informatie is opgenomen over de benoemingsprocedure, de duur van de benoeming, het aantal uren dat de docent krijgt voor de rol, wie verantwoordelijk is voor de beoordeling, en dergelijke.

\section{Stap 4. Geef een indicatie van het type on- derwijsrollen}

Onderwijsrollen variëren in type. Om een onderscheid te maken tussen de verschillende typen onderwijsrollen kan gebruik gemaakt worden van de docentopvattingen van Darling-Hammond et al. ${ }^{8} \mathrm{Zij}$ onderscheiden twee soorten onderwijsrollen, die zij typeren als 'labor/craft' en 'profession/art'. Onderwijsrollen die getypeerd worden als labor/craft zijn gericht op de uitvoering van onderwijs. De docent is uitvoerder van onderwijs dat door anderen is ontwikkeld en wordt voorgeschreven. Slechts binnen beperkte marges heeft de docent de mogelijkheid om het onderwijsprogramma naar eigen inzicht vorm te geven. De docent heeft dus weinig autonomie.

Onderwijsrollen die getypeerd worden als profession/art zijn docentrollen waarbij docenten zelf verantwoordelijk zijn voor de ontwikkeling, uitvoering en inrichting van het onderwijs. Bij profession/art onderwijsrollen beschikt de docent over veel autonomie.

Voorbeelden van onderwijsrollen met veel autonomie zijn managementrollen, coördinerende rollen en onderwijsontwikkelingsrollen. Voorbeelden van rollen met weinig autonomie zijn uitvoerende rollen, zoals trainer of tutor. 
Stap 5. Bepaal welke meetinstrumenten gebruikt worden voor de beoordeling van een onderwijsrol

Is het primaire doel van de beoordeling het geven van feedback aan individuele docenten, dan liggen met name diagnostische instrumenten voor de hand. Dit zijn instrumenten die gericht zijn op het verschaffen van feedback op basis waarvan de docent zijn gedrag kan bijsturen. Is het primaire doel gericht op selectie, dan gaat de voorkeur uit naar screeningsinstrumenten. Deze instrumenten zijn bedoeld om te beoordelen of het gedrag van de docent in een bepaalde rol voldoende of onvoldoende is. Diagnostische instrumenten zijn uitgebreider van opzet dan screeningsinstrumenten.

\section{Stap 6. Ontwikkel een opslagsysteem voor docentbeoordelingen}

Van docenten die onderwijsrollen vervullen, dienen beoordelingen beschikbaar te zijn over de kwaliteit van de onderwijsprestaties. Hiervoor is de onderwijsorganisatie verantwoordelijk. De beoordelingen moeten makkelijk toegankelijk zijn. Een centraal opslagsysteem verdient de voorkeur. Het is raadzaam de beoordelingen in dit systeem te ordenen op diverse niveaus, bijvoorbeeld per docent, per onderwijsrol en per capaciteitsgroep. Op deze manier kunnen gegevens op diverse niveaus inzichtelijk gemaakt worden en desgewenst als uitgangspunt voor verbetering of verandering aangewend worden. Dit vraagt om een elektronisch en geautomatiseerd opslagsysteem. Afspraken zijn vereist over de aard en detaillering van de gegevens die opgenomen worden. Bovendien dienen verantwoordelijkheden gedefinieerd te worden, zoals wie de docentgegevens regelmatig invoert (up-to-date) en wie toegang heeft tot het systeem (bewaking privacy van docenten).
Stap 7. Zorg dat de eisen voor promotie op onderwijsgebied schriftelijk zijn vastgelegd Op centraal niveau moet geformuleerd zijn op welke wijze onderwijsprestaties betrokken worden bij de loopbaan van medewerkers en op welke wijze profilering op onderwijsgebied mogelijk is. Dit vraagt om duidelijke regels, die ook schriftelijk zijn vastgelegd. Bijvoorbeeld duidelijkheid over het type, de kwantiteit en de kwaliteit van de onderwijsrollen die iemand moet vervullen alvorens hij in aanmerking komt voor een functie als universitair hoofddocent of een hoogleraarschap. Deze regels winnen aan kracht indien ze landelijke erkend worden. De discussie over de mogelijkheden van onderwijsprofilering spelen landelijk al enige tijd, maar er is nog geen sprake van een eenduidig beleid. ${ }^{2}$

\section{Stap 8. Zorg voor scholingsmogelijkheden om professionalisering van docenten te stimuleren} Belang hechten aan goed onderwijs vereist dat docenten over bekwaamheden op het gebied van onderwijs beschikken. Hiervoor is scholing vereist. Indien in de praktijk blijkt dat docenten over onvoldoende bekwaamheden beschikken, moet de mogelijkheid gegeven worden tot bijen herscholing. Docenten die zich verder willen profileren op onderwijs dienen bovendien extra mogelijkheden te krijgen om zich te professionaliseren. Een dergelijk beleid is tot op heden nog onvoldoende ontwikkeld. De Visitatiecommissie Geneeskunde onderschrijft dit en toont zich voorstander van een beleid waarin meer aandacht is voor onderwijskundige professionalisering. ${ }^{2}$ Kortom: een systeem van docentbeoordeling veronderstelt een professionaliseringsbeleid en een scholingsprogramma voor docenten. Het management is hiervoor verantwoordelijk. 6 
Stap 9. Zorg voor voorlichting over het beoordelingssysteem

De introductie van een beoordelingssysteem voor docenten vraagt de nodige tijd en aandacht van het management. De bruikbaarheid van een beoordelingssysteem neemt toe naarmate de acceptatie ervan groter is. Het is bekend dat acceptatie bevorderd wordt wanneer voldaan is aan enkele voorwaarden. De gebruikers moeten de relevantie van het systeem inzien en de informatie die opgenomen is in het beoordelingssysteem moet geloofwaardig zijn. De rapportage van gegevens moet duidelijk zijn. Bovendien moet de gebruiker betrokken zijn bij de opzet van het systeem. Een goede communicatie met docenten over opzet, doel en gebruik van een beoordelingssysteem is onmisbaar. ${ }^{9}$

\section{Stap 10. Zorg voor kwaliteitscontrole}

Als laatste geldt dat het onderwijsmanagement regelmatig controleert of het systeem bijgesteld moet worden. Bovendien moet bekeken worden of de stappen met de bijbehorende activiteiten ook nageleefd worden. Bijvoorbeeld: eisen voor promotie (stap 7) kunnen schriftelijk vastgelegd zijn, maar dit impliceert niet automatisch toepassing hiervan in de praktijk.

Een overzicht van de tien stappen is opgenomen in figuur 1.

\section{Ten slotte}

De beschrijving van het stappenplan is een praktische benadering om te komen tot een beoordelingssysteem voor docenten. Het is een eerste aanzet hiertoe. Wanneer gesproken wordt over bekwaamheden waarover docenten voor bepaalde onderwijsrollen moeten beschikken, dan moet een vertaalslag gemaakt worden naar de benodigde competenties van docenten. Welke competenties dit precies zijn, vereist verdere discussie en onderzoek. Hetzelfde geldt voor de maatstaven die gehanteerd worden voor goede versus slechte onderwijsprestaties.

Het beoordelingssysteem is enerzijds gericht op het nemen van beslissingen over goede en slechte onderwijsprestaties van docenten en anderzijds op het verbeteren van onderwijsprestaties. Tussen beide bestaat een spanningsveld. De kunst is om een balans te vinden. Profilering op het gebied van onderwijs zal niet voor alle docenten gelden. Indien een docent dit wenst en een onderwijscarrrière nastreeft, dan is er behoefte aan uitvoeriger informatie over zijn onderwijsprestaties. In dergelijke gevallen is een portfolio nuttig. Indien deze docent opteert voor een bepaalde onderwijsfunctie, dan moet uit de portfolio blijken dat de docent beschikt over de benodigde bekwaamheden. De 'bewijslast' ligt

Figuur 1. Overzicht van het stappenplan voor een systeem van docentbeoordeling.

1. Formuleer wat het doel is van een systeem van docentbeoordeling.

2. Inventariseer en benoem alle onderwijsrollen.

3. Maak voor elke onderwijsrol een taakomschrijving.

4. Geef een indicatie van het type onderwijsrollen.

5. Bepaal welke meetinstrumenten gebruikt worden voor de beoordeling van een onderwijsrol.

6. Ontwikkel een opslagsysteem voor docentbeoordeling.

7. Zorg dat de eisen voor promotie op onderwijsgebied schriftelijk zijn vastgelegd.

8. Zorg voor scholingsmogelijkheden om professionalisering van docenten te stimuleren.

9. Zorg voor voorlichting over het beoordelingssysteem.

10. Zorg voor kwaliteitscontrole. 
dan niet bij de onderwijsorganisatie, maar bij de docent zelf. Daarentegen zal de onderwijsorganisatie tot op zekere hoogte willen beschikken over informatie over de wijze waarop onderwijsrollen zijn uitgevoerd. Tot op heden is er nog weinig ervaring opgedaan met portfolio's voor docenten. Bij diverse onderwijsinstellingen is het gebruik van portfolio's voor docenten tot speerpunt uitgeroepen. Komende tijd zijn er dan ook ontwikkelingen op dit terrein te verwachten.

Met de invoering van een docentbeoordelingssysteem kan het belang van onderwijs niet worden afgedwongen. Hiervoor is een cultuuromslag nodig, die ertoe leidt dat onderwijs hoog op de agenda staat. Alleen dan is een beoordelingssysteem voor docenten zinvol en zal het in de praktijk een daadwerkelijke functie vervullen. 1011

\section{Literatuur}

1. Levinson W, Rubenstein A. Missions critical. Integrating clinical-educator into academic medical centers. N Engl J Med 1999; 314/11:840-3.

2. Vereniging van Samenwerkende Nederlandse Universiteiten. Onderwijsvisitatie Geneeskunde en Gezondheidswetenschappen. Utrecht: VSNU; 1997.

3. Nutter DO, Bond JS, Coller BS, D'Alessandri R, Gewertz BLK et al. Measuring faculty effort and contributions in medical education. Acad Med 2000;75:2001-7.

4. College van Bestuur Universiteit Utrecht. FLOW: Functies loopbanen en waardering. Utrecht: Universiteit Utrecht; 1994.
5. Sachdeva AK, Cohen R, Dayton MT, Herbert JC, Jamieson C, Neumayer LA, et al. A new model for recognizing and rewarding the educational accomplishments of surgery faculty. Acad Med 1999;74:1278-8.

6. Steinert Y. Faculty development in the new millennium: key challenges and future directions. Med Teach 2000;22:44-50.

7. Evelein F, Tartwijk J van. Overwegingen bij het gebruik van portfolio's binnen een universitaire lerarenopleiding. Velon Tijdschrift voor Lerarenopleiders 1999;21:46-55.

8. Darling-Hammond L, Wise AE, Pease AE. Teacher evaluation in the organisational context. Review of Educational Research 1983;53:258-328.

9. Cousins JB, Leitwood KA. Current research on evaluation utilization. Review of Educational Research 1986;56:331-64.

10. Johnson NJ, Rose LM. Portfolios. Clarifying, constructing and enhancing. Technomic: Lancaster; 1997.

11. Tartwijk J van. Een model voor portfolio's met als doel beoordeelbaarheid en het stimuleren tot reflectie. Universiteit Utrecht: IVLOS, 1999.

De auteurs:

H.A.P. Wolfhagen en D.H.J.M. Dolmans zijn als onderwijskundigen verbonden aan de Capaciteitsgroep Onderwijsontwikkeling en Onderwijsresearch.

L.F.J.Th.M. Kolle is hoofd Bureau Onderwijs van het Onderwijsinstituut.

A.J.J.A. Scherpbier is wetenschappelijk directeur van het Onderwijsinstituut.

Allen zijn verbonden aan de Faculteit der Geneeskunde van de Universiteit Maastricht.

\section{Correspondentieadres:}

H.A.P. Wolfhagen, Universiteit Maastricht, Capaciteitsgroep O\&O, Postbus 616, 6200 MD Maastricht. E-mail: i.wolfhagen@educ.unimaas.nl.

\section{Summary}

Teaching is playing an increasingly important role in faculty career development. This means that teaching efforts and accomplishments must be evaluated. This article describes a number of steps in an approach to systematic teacher assessment. (Wolfhagen HAP, Dolmans DHJM, Kolle LFJThM, Scherpbier AJJA. Steps towards systematic teacher assessment. Dutch Journal of Medical Education 2000;19(6): 214-217.) 